\title{
Patients' rights ruling: A bitter pill for doctors to swallow
}

India's medical community is up in arms about a recent Supreme Court ruling handed down in mid-November that says the consultation, diagnosis and treatment services rendered by doctors and hospitals for a fee should be treated much like any other service and, as such, should fall within the purview of the 1986 Consumer Protection Act. This now clears the way for patients to file medical malpractice lawsuits in consumer - rather than civil courts for more speedy decisions. Only government-run hospitals and doctors providing free medical services will be exempt.

Consumer-rights activists and the public called the ruling a landmark judgment, saying it was long overdue and hoping that it will lead to an improvement in the accountability of doctors and the quality of services provided in the private sector. (About 80 percent of India's 400,000 registered medical practitioners are in private practice.) They point to several cases of negligence in state-run and private hospitals, the most recent of which occurred in October at the All India Institute of Medical Sciences Hospital in New Delhi, where three cataract patients lost their eyesight because of a hospital-acquired infection.

But many within India's medical community fear that the ruling will open the floodgates to a wave of false and frivolous lawsuits, because it costs nothing to bring a case in consumer court. Under the Act, however, anyone found making false allegations will be slapped with a fine of up to Rs 10,000 (US\$300), the equivalent to six month's salary on average.

Before the ruling, medical malpractice cases could only be brought in civil court, which meant hiring a lawyer and paying hefty court fees, equal to 10 percent of the compensation claimed. Judgments also tend to be quicker in consumer courts six months at most, as opposed to years. It took 13 years for a court to order the government's Willingdon Hospital in New Delhi to pay $\$ 3,000$ in damages to relatives of a girl who had died in 1982 of a hospital-acquired tetanus infection. And, almost 10 years elapsed before a top tabletennis player, crippled by a surgery carried out in a private hospital in Madras in 1984, was awarded $\$ 50,000$ in compensation.

In the past, suing doctors has been so costly and time-consuming that only three out of 416 tort cases decided by all of India's courts during the ten-year period 1975-1984 involved medical malpractice.
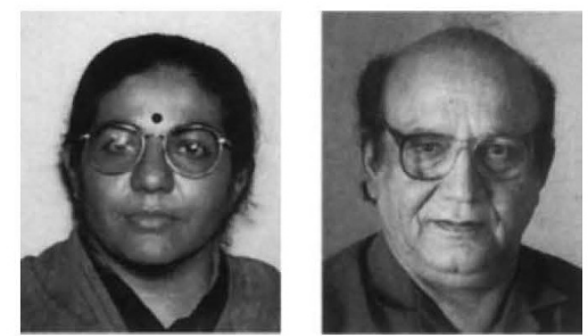

On opposite sides of the debate concerning patients' rights in India: Mira Shiva (left) and Jagdish Sobti.

The 36,000-strong Indian Medical Association says it is determined to fight it out - even if that calls for a nationwide strike. "We have to abide by the law, but agitation is our right," says Jagdish Sobti, the association's secretary. There is no appeals process. But the medical association, after a two-day emergency meeting held shortly after the ruling was handed down, decided to file a petition with the court requesting a review of the decision by the full bench of seven judges. (The present ruling was given by three justices.)

"Legislation is not the real cure to our ailing health care system," says Mira Shiva of the Voluntary Health Association of dote to the greed of the medical profession that has converted illness into industry." The voluntary health association is also calling for government-run hospitals to be held accountable under the Act.

But the medical association warns that the ruling will likely force doctors to increase their insurance liability coverage and to practise "defensive" medicine, the costs of which inevitably will be passed on to the consumer. Insurance companies have already hiked their annual premium rates for medical practitioners from about

Naresh Trehan, a cardiac surgeon at the Escorts Heart Institute in Delhi, says that reducing medical practice to a trade will only encourage doctors to behave like traders and turn away high-risk cases. And, Dwarkadas Motiwala, a pediatrician who runs a charity hospital in New Delhi, says he doubts whether patients will really benefit from the recent ruling. "It will surely allow lawyers to make hay."

K.S. JAYARAMAN New Delhi India in New Delhi, "but it is the best anti$\$ 4$ to $\$ 128$.

\section{EPO caught in mouse maze}

The question of whether or IMAGE not companies can obtain UNAVAILABLE 300 other applications are pan-European patents on FOR COPYRIGHT: on hold, pending the out-

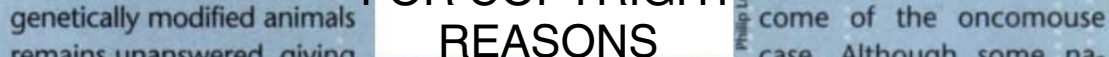
remains unanswered, giving REASONS case. Although some naa temporary victory to opponents of animal patenting. Despite advance suggestions of issuing a clear decision, the opposition board of the European Patent Office (EPO) failed to resolve a dispute over the validity of the patent granted by the EPO for the socalled "Harvard oncomouse" in 1992. The EPO opposition board hearing at the end of November, which was designed to consider arguments of animal rights groups, broke up without reaching a conclusion because there was too much evidence to consider in the three days allotted. The proceedings will continue in writing, and the EPO says it will not be setting a timetable for their conclusion.

The failure to reach a decision, and the announcement of an indefinite period for deliberation, has angered lawyers on both sides of the issue. The delay also has serious consequences for anyone seeking patent protection of genetically engineered ani- tional patent offices have awarded patents on genetically modified animals, this is a much more expensive way of getting protection than obtaining a single panEuropean patent. According to an EPO official, the only other animal patent granted by EPO is held by Transgene, a French biotechnology company located in Strasbourg. Transgene's patent covers any animal carrying a particular cell line, providing it acquired it by the process described in the patent.

The oncomouse, which belongs to Du Pont of Wilmington, Delaware, under a licensing agreement with Harvard University, has not been an overwhelming commercial success. However, it is an important test case in determining the feasibility of obtaining pan-European patents on animals.

Nuala Moran London 